Agata M. Balińska (D)

University of Warsaw

agata.balinska@uw.edu.pl

\title{
The Intralingual Translation or Rewording of British and American Literary Works on the Basis of Children's and Young Adult Literature
}

\section{The idea of intralingual translation between British and American English}

The beginning of the seventeenth century, when the first British colonists set foot on the American continent, proved to be a turning point in the history of English language. From this moment on, the varieties of the English language used in the British Isles and the ones used in the present-day United States started to drift apart. Because of these differences, some began to see the necessity for translations of texts created in one variety of English into the other.

Usually, it is British texts that are edited before they enter the American market, although, in some cases, the opposite process takes place, with American texts being altered for the benefit of the British audience. Children's literature is often "translated" in that way, as there seems to be a common belief that a text in one of the varieties of English might be too difficult for children and young adults, or for adults choosing the 
reading material for young readers who use the other variety on a daily basis. However, there are also cases of such editions of texts targeted at adult readers.

Such translations fall into the category of what Roman Jakobson in On Linguistic Aspects of Translation calls "intralingual translation" [Jakobson 1987: 429] and in this paper, I shall alternately refer to this sort of intralingual translation as translation, adaptation, edition, version, or altered version. Many of the examples listed in this paper are taken from a two-part article by Jane Whitehead 'This is not what I wrote!': The Americanization of British children's books" published in 1996 and 1997 in Horn Book Magazine. Examples of changes in American versions of the Harry Potter book series were taken from my unpublished research, and since the series by J. K. Rowling is the most voluminous of the titles listed below, it provides the largest corpus of changes in the American version in comparison to the British original. The series is also very well-known to a mass audience, with interlingual translations into many languages.

The aim of this paper is to raise awareness of the intralingual translations between British and American English, especially in children's literature, as the existence of these translations is not widely recognized, and since there might be cases where the adaptation is used as a source text for the interlingual translation. ${ }^{1}$

\section{British and American English}

The English language is the world's third most spoken language, with approximately 379 million first-language speakers spread across six continents in 99 countries [David, Simmons and Fening 2019]. This vastness of number and geographical distribution of English is one of the reasons for its great diversity. The birthplace of the English language is the British Isles, but it is the United States which today is home to nearly $70 \%$ of the world's English mother-tongue speakers [Crystal 1997: 60].

Despite the fact that often differences between British English and American English are exaggerated as far as claiming lack of intelligibility,

Judging by the presence of certain passages that were absent from the British original but can be found in the American version it is possible that the American edition was used for some translations, e.g. the Polish translation of the first book and the Russian translation of the first three books. 
American English is not recognized as a separate language but rather as a variety of the English language [Janicki 1977: 12] that differs in many aspects from the variety of English used in Britain. There have, however, been attempts at changing this status, Noah Webster's American Dictionary of the English Language being probably the most prominent of them. This trend was continued, among others, by H. L. Mencken in his The American Language, published almost a century after Webster's dictionary. In his work, Mencken focused on the spoken language and thus saw "the American form of English" as "departing from its parent stem" [Marckwardt and Dillard 1980: 7]. A different view on the matter was adopted by G. P. Krapp, the author of The English Language in America, who stated that "historical and comparative study brings American English in closer relation to the central tradition of the English language than is commonly supposed to exist" [Marckwardt and Dillard 1980: 7].

The titles of the works by Mencken and Kapp reflect the different attitudes adopted towards American English. So far it has not gained the status of a language, and it is doubtful whether American English will become recognized as one in the near future. The differences between American and British versions of English do not make the utterances of one person from one side of the Atlantic unintelligible to their interlocutor from the other side. Still, the differences cannot be disregarded, and neither should American English be perceived only as a dialect of English. In this thesis dissertation, regardless of the well-known aphorism attributed to Max Weinreich that "a language is a dialect with an army and navy" [e.g. Shell 2002: 153] and a very unstable differentiation between what is referred to as a dialect or a language, which is rather a political distinction than a linguistic one [Janicki 1977], I shall refer to both American English and British English, as they are the main focus of the said work, as (national) varieties of English.

Also, one should not overlook the fact that British English and American English are by far not the only varieties of English. Canadian English, New Zealand English, South African English, Australian English and Hong Kong English are among many varieties of English that have many distinctive features which have stemmed from historical, cultural, geographical, national, political and communicative factors. As Janicki states: "[...] it can be concluded that different varieties of English [...] have national identities whereas the English language as such does not." [Janicki 1977: 12] 
The processes that caused the differences between today's British and American English have developed in America after the colonists settled there and in Britain after colonists left the Old Country or, as Marckwardt points out in his work American English, have taken place "in both divisions of the language after the original period of settlement" [Marckwardt and Dillard 1980: 11]. These tendencies can be easily seen when one takes into account some of the differences between the two varieties in the vocabulary used today. The phrase "pig sty" has been preserved in such form in British English but on the other side of the Atlantic Ocean the phrase "pig pen", which developed after the colonists came to America, is used [Marckwardt and Quirk 1964]. In the case of words that have retained their original form in America but changed in the Isles, the pair "fall" (season) "autumn" is a good example, the term "fall" gradually becoming obsolete in Britain and gaining popularity in America [Janicki 1977]. There are also many cases of words referring to concepts that have developed after American English came into being and very often their denotations differ, e.g. "elevator" in America and "lift" in Britain; "gas" or "gasoline" in the United States and "petrol" in the United Kingdom, etc.

Today the dominance of American science and culture in the media and the Internet means that an increasing number of "Americanisms" have been finding their way into other varieties of English. Words that not long ago were considered unquestionably American are now used in the British Isles on a daily basis. In turn, the popularity of some British television series in the United States, such as BBC's Dr Who and Sherlock or ITV's Downton Abbey (more examples can be found in Miller 2000) and the fact that American school curricula include English literary classics is proof that British English is definitely understandable in America.

\section{English language children's literature in (intralingual) translation}

English literary works that were created on one side of the Atlantic often undergo certain changes before they enter the market across the ocean. The general aim of such changes is to rid the text of items that are perceived, usually by publishing companies, as a threat to the marketing success of the work or, as they believe, make the text more peculiar and less adjusted to the conventions of a given variety of English [Whitehead 1996, 1997]. This trend for "adaptations" of British texts before they are 
available to the American audience is not a recent phenomenon. There are also American texts which undergo changes before they enter the British market, but this is a smaller phenomenon. Children's and young adult literature is especially prone to such modifications, but some books intended for adult readers have also been altered. The authors of such changes are usually anonymous and sometimes it is the authors of the texts, who themselves alter their work to satisfy the needs of readers, or rather of implied readers, across the Atlantic (see Influence of the publisher and changes by the author below).

The immediate answer to the question of why books written in one variety of English are "translated" into the other variety is to make the target text comprehensible in the same way as the source text (see a fragment of Arthur Levine's interview below). However, the scope of changes in some cases seems to suggest that maximizing marketability is also a contributing factor [Whitehead 1996]. Children's and young adult literature occupy an interesting position in most markets. Even though the primary target audience of literary works that can be classified as children's and young adult literature are children (or young readers), they also have an audience of adults in editors, publishers, parents, educators, etc. It is the last group that usually defines to what texts the target audience gains access. There are also texts that have what Zohar Shavit [1986] called in Poetics of children's literature "ambivalent status". Such texts have the "simultaneous (often contradictory) need to appeal to both the child and to the adult" [1986: 63]. A noteworthy fact is that, as Julia Briggs puts it, “children's books are written for a special readership but not, normally, by members of that readership; both the writing and quite often the buying of them, is carried out by adult non-members on behalf of child members" [1989: 4]. This is the case with translations of texts for children, as they are also not created by members of this audience but by adult translators.

Studies on children's literature in translation provide many examples of translation (albeit mostly interlingual) where translators have taken many liberties. In children's literature, heavier manipulations are much more common than in adult literature. Shavit sees the reason for that in "the peripheral position of children's literature within the literary polysystem" [1986: 112]. Göte Klingberg in his Children's fiction in the hands of the translators focuses on the "degree of adaptation", that is the "degree to which the text is adapted to the intended readers" [Klingberg 1986: 11] and "cultural context adaptation", which is translators" "further 
adaptation of the adaptation to new readers" when there is a danger that "the degree of adaptation of the target text will be less than that of the source text" [Klingberg 1986: 11-12]. In Klingberg's opinion context adaptation should be "restricted to the details" and "not tried when not absolutely necessary" [Klingberg 1986: 17]. He [1986; 2008] also draws a strong division between cultural context adaptation and other types of changes, for instance purification, didactizing and abridgment. Purification is "undertaken with regard to real or assumed set of values of the addressees" and as far as children's literature is concerned "the values of adult intermediaries" are usually taken into account [2008: 15]. Didactizing can be understood as an introduction of a didactic element in the target text that was not present in the source text [2008]. This concept has a long tradition not only in translation but in the original as well, and it can be seen today not only in literary works but for example in adaptations of animated and live-action television series. ${ }^{2}$

\section{British and American spelling, punctuation and grammar}

Probably the most obvious area of adaptations of originally British texts in the United States is spelling. After all, both of these varieties of English differ in this respect. In most cases modern British spelling of words follows Samuel Johnson's A Dictionary of the English Language from 1755 and American spelling is mostly based on Noah Webster's dictionaries of 1806 and 1828, A Compendious Dictionary of the English Language and An American Dictionary of the English Language. The main spelling differences that are to some degree regular and clearly visible in present-day British (which usually also means English used in the Commonwealth) and American English are: British -ou- and -o- in American English, ${ }^{3}$

2 E.g. American adaptation of Japanese Sailor Moon animated series which had special advice segments added that mimicked similar segments in the American series Captain Planet and the Planeteers - both produced by DIC Entertainment Corporation in the USA.

3 The deletion of $-u$ - is most commonly seen in the change of the suffix -our into -or whenever it is unstressed, such as in words: "colour", "armour", "favour", "rumour", "parlour", which in American spelling change into "color", "armor", "favor", "rumor", "parlor" respectively [Janicki 1977: 48; Mencken 1919: 248; c.f. Peters 2004: 359, 397, 504]. 
British -re and American -er, ${ }^{4}$ British -ce changed into American -se, ${ }^{5}$ British $-s$ - and American $-z-,{ }^{6}-a e$ - and -oe- versus $-e-,{ }^{7}$ double consonants and single consonants. ${ }^{8}$

4 Some words of Greek, Latin or French origin in British English end with a consonant followed by an unstressed -re pronounced / $\mathrm{a} /$. These words in American English end with the -er, e.g. British "centre", "sombre", "theatre" become "center", "somber" and "theater" in American English [c.f. Peters 2004: 461, 542-543; Hoad 1986].

5 For most nouns ending in -ce in British English, -se is used in American English, thus "defence", "licence", "offence", "pretence" in British are spelled "defense", "license", "offense" and "pretense" in the United States [Janicki 1977: 51; Peters 2004: 98-99].

6 This change is vividly noticeable in two groups of words: namely verbs of Greek origin ending with the suffix -ise in British English, which changes into -ize in American English, e.g. "apologise", "realise", "recognise" change into "apologize", "realize", "recognize" and nouns of Greek origin containing the British suffix -isation, which in American English transforms into -ization, changing such words as "organisation", "generalisation" into "organization", "generalization" [Janicki 1977: 4; Peters 2004: 298-299, 590].

7 Many of the words that contain -oe- and -ae- in British English are spelled with -e- in American English, e.g. "aesthetics" or "diarrhoea" are usually spelled "esthetics" and "diarrhea" in the United States [Janicki 1977: 51; Peters 2004: 20]. Some of the words originally containing - ae- or -oe- can be spelled either way in British English, e.g. "encyclopaedia" or "encyclopedia" and "mediaeval" or "medieval", others keep -ae- and -oe- in both varieties of English, e.g. "phoenix", with the exception toponym "Phenix" [Peters 2004: 20, 389].

8 In British English the final $-l$ is doubled before most suffixes in unstressed syllables when $-l$ is preceded by a single vowel. This is usually not the case in American English, hence "cancelled", "quarrelled", "travelling" and "traveller" in British English, but "canceled", "quarreled", "traveling", and "traveler" in American English. The single $-l$ in such cases is the standard spelling in the United States, while in Britain this varies [Peters 2004: 309, 502, 547]. However, the opposite process can sometimes be observed when the syllable is stressed, e.g. British spelling is "skilful", "fulfil" and "fulfilment" and in in the United States the spelling is "skillful", "fulfill" and "fulfillment" [Janicki 1977: 50]. The spelling "program" is the standard spelling in the United States for all uses of the word and in Britain it is reserved chiefly for use in computing. In all other meanings the British use "programme". "Program" is the earlier spelling of the two, making its first appearance in (Scottish) English in the seventeenth century [Peters 2004: 442-444]. 
Another similar area is punctuation and grammar. There are relatively few differences between British and American English in punctuation. In American English "Mr.", "Mrs.", "Ms.", etc. take periods, while in British English they do not, following the rule that a period is used only when the last letter of the abbreviation is not the last letter of the complete word. As Peters suggests, this might have also resulted from the distinction between abbreviations and contractions [Peters 2004: 126, 359]. Americans use double quotes ("') for initial quotations and single quotes (") for quotations within the initial quotation and the British do the reverse. It is often considered unusual to use the Oxford comma before "and", as well as "or", though American English makes frequent use of that [Trask 1997] as American editorial practice described in the Chicago Manual insists on using a comma before the conjunction "and" located between the last two items when three or more items are being enumerated [Fowler and Bruchfield 1996: 162; Peteres 2004: 115, c.f. Lovinger 2000: 382]. The differences in grammar between American and British English are more difficult to observe than those concerning spelling and punctuation. Many occurrences considered to be typical American English are also found in certain dialects in the United Kingdom, and grammatical differences in written language often do not overlap with those in spoken language. ${ }^{9}$ It can be argued, with a reasonable degree of certainty, that spelling, punctuation and grammatical alterations in literary texts targeted for younger audiences serve the purpose of learning and memorizing the correct spelling, punctuation and grammar by the said young readers in the particular variety of English, i.e. in most of the cases in this study, of American English spelling and punctuation.

\section{Lexical differences}

The area of most interest for this paper are changes in lexical items. As with any other aspect of differences between British and American English, here too the number of similarities outweighs the number of

9 For an overview of grammatical differences between British and American English c.f. Janicki 1977: 86-101, and for more details c.f. Peterson 2004: 489 (modal verbs "shall" and "will"); 161, 560 (auxiliary verb "do"); 520-521 (the subjunctive mood); 50, 264, 272, 390-391, 393, 400-401, 438, 540, (prepositions and adverbs); 1, 49 (articles); 51 (tenses); 23-25, 173, 229, 322, 423, 487, 512 (morphology of verbs); 96, 548 (transitivity). 
discrepancies. The corpus of vocabulary differences in both varieties of English came into being as a natural result of the different circumstances to which they were exposed. From early on in order to name unknown objects Americans were forced to either borrow words from other languages or to coin terms of their own [Janicki 1977]. There are few if any languages that might be called "pure" and English in that respect is no exception. On the contrary, it has been, as Marckwardt deems it, "a notorious word borrower" [1980: 25]. The history of contact with other cultures and languages is one of the reasons for this tendency. This was and still is the case in Britain as well as in America. When English colonists reached America, they were faced with the unknown, and the plants, animals and objects new to them had to be given names. Thus, many names were borrowed from indigenous languages as well as from other colonists of European origin. Some have travelled across the Atlantic to the British Isles. ${ }^{10}$

Lexical changes to British literary texts in the United States take many forms. Some might be justified in the same way as spelling, punctuation and grammatical changes mentioned above, but some changes are questionable. There are cases where titles, names of the characters and places are changed in American editions. Many British words are not only replaced with their American equivalents, but are often changed or removed, and sometimes even passages are added, removed, or rewritten. There are also cases when the edited version corrects some mistakes that occurred in the original version, as is sometimes the case in the Harry Potter series by J. K. Rowling (see below). It might be argued that the translator should not correct mistakes made by authors of literary texts, although this tendency is especially noticeable in the literary translation of children's literature [Hejwowski 2004: 232].

\section{Changes in British texts on the American Market}

American adaptation of British literary texts is not a recent phenomenon. Dickens' Martin Chuzzlewit contains many unflattering remarks about Americans which were removed from the American version in the latter half of the nineteenth century so that the sales of the book would not

\footnotetext{
10 Marckwardt [Marckwardt and Dillard 1980] provides a detailed list of borrowings from American languages as well as the languages of European non-English settlers and immigrants. Janicki also provides such a list in his Elements of British and American English [1977: 55-72 and 73-84].
} 
be affected [Chaudhuri 2000]. However, in the case of British literature for children translated for the American market, many editors admit that "the merest whiff of Britishness scented by a reviewer may be considered a strike against the book in a tough market" [Whitehead 1996]. The market is demanding, and the assumption is that any item which might not be understandable to American children, or even more importantly regarding books for the youngest readers, American parents, might cause sales to plummet. It is believed that retaining too many Briticisms will add unnecessary confusion to the book. Also, a parent might not know the meaning of a word that is left in its British form, which might cause embarrassment more on the part of the adult than of the child [Whitehead 1996].

The number of changes generally depends on many factors, e.g. the age of the readers (the younger the child, the more alterations). However, as Whitehead mentions, what also matters are

the reputation of the author, past experience with the author, and the intended market. An author with a track record and a bankable name can often negotiate for minimal changes, while the less well-known may face extensive rewrites [Whitehead 1996].

Books intended for the mass market are most likely to be heavily edited, as any hint of foreignness might potentially discourage the mass audience from making the purchase.

Often British or British-sounding vocabulary is changed. "Post" becomes "mail", "jumper" turns into "sweater", "taps" are changed into

11 I have found that, e.g. in the first two books in the Harry Potter series, this change is quite consistent. The word "post" in the sense of delivery of letters and parcels is used in Harry Potter and the Philosopher's Stone twelve times and each time it is changed to "mail" in Harry Potter and the Sorcerer's Stone. In Harry Potter and the Chamber of Secrets "post" in this sense is used two times and again in both cases this is changed to "mail" in the American version. However, in Harry Potter and the Prisoner of Azkaban it is used four times and it is changed only once into "mail" and also once into "burden".

12 In the first two books in the Harry Potter series the word "jumper" is changed into "sweater" 16 times, see: J. K. Rowling (1997), Harry Potter and the Philosopher's Stone. London, Bloomsbury Publishing. 32, 217, 219, 220, 331; J. K. Rowling (1998). Harry Potter and the Sorcerer's Stone. New York: Scholastic Press. 24, 200, 202, 203, 308; J. K. Rowling (1998), Harry Potter and the Chamber of Secrets. London, Bloomsbury. 57, 58, 159, 165; J. K. Rowling 
"faucets". ${ }^{13}$ These changes might trigger more alterations as they might modify the whole text. In her two-part article Whitehead [1996, 1997] provides many examples of such changes. In the British Tiddlers, written by Catherine and Laurence Anholt and published in the USA as Toddlers, the word "nappy" was removed, as the passage "I am sad, I am happy, I want Mum to change my nappy" was rewritten as "I am sad, I am sweet, I can stand on my two feet" [Whitehead 1996]. In "Andrew McAndrew and the Taps", in the book Andrew McAndrew by Bernard MacLaverty (published by Walker in the UK and Candlewick in the US in 1989), the change of "taps" into "faucets", triggered some changes inside the book: "Tap tops. The top of the taps. Tap tops." become "Faucet fixtures. The fixtures of the faucets", and "One, two, three. Steady now, chaps, Let's help Grandad with his taps." turns into "One, two, three. Steady now, mister, Let's help Grandad with his fixtures." All these make quite substantial changes to the style as well [Whitehead 1996]. If the text is read aloud to the child, the combination of "faucets" and "fixtures" might be difficult to pronounce for the reader. It is not only the actual British words but also words with any "whiff of Britishness" that are in danger of alteration or removal. In Garry Kilworth's The Electric Kid (published in the United States by Orchard in 1995) American editors found the invented words "skidder", "swazz", "yerky", and "kerk" "too British-sounding", much to the author's surprise, who actually took the word "kerk" meaning "guy" from Captain Kirk of Star Trek, which is no doubt an American source. They remained in the book as such only after the author's intervention [Whitehead 1996]. Even words that would not be clear to young readers in most parts of Britain are changed in American versions of books. June Oldham's Foundling, published by Hodder in Britain and by Orchard in the USA under the title Found (both first released in 1995) includes some words from Yorkshire, which is the setting of the book. "Becks" and "gills" became "streams" even though they are foreign not only to American readers [Whitehead 1997].

(1999), Harry Potter and the Chamber of Secrets. New York, Scholastic Press. 72, $73,212,213,222$.

13 One such example is Andrew McAndrew by Bernard MacLaverty (see below). 


\section{Changes to titles}

Titles also change, their "Britishness" or foreign items forcibly removed. The above-mentioned Foundling becomes Found and Tiddlers is changed to Toddlers. "Tiddler' is a Victorian nursery name for a minnow or small stickleback, ${ }^{14}$ and the meaning would be clear to British readers by analogy with 'tiddly', meaning 'small"' [Whitehead 1996]. The tooBritish-sounding Dog Dottington by Diana Hendry (published by Walker in 1995) turns into Dog Donovan (published by Candlewick in 1995) [Whitehead 1996], Grandad Pot (published by Walker in 1993) by Siobhan Dodds appears as in the United States as Grandpa Bud (published by Candlewick in 1993) [Whitehead 1996] and Rowling's Harry Potter and the Philosopher's Stone, first published by Bloomsbury in 1997, changed into Harry Potter and the Sorcerer's Stone when published in the USA by Scholastic in 1997. This is one of the most significant changes in the Harry Potter series and with it the readers of the American version are deprived of a real-world context. Being a well-established term, "Philosopher's Stone" has certain historical and cultural connotations which "Sorcerer's Stone" lacks. The philosopher's stone was sought after by alchemists for its supposed ability to transform base metals into gold and other precious metals. It was also believed to produce the "elixir of life" (this information is also provided in the text of the book). The quest for the philosopher's stone continued from the Middle Ages to the seventeenth century, and the alchemists' research laid the foundations for the sciences of chemistry, metallurgy, and pharmacology. ${ }^{15}$ Moreover, this volume of the Harry Potter series includes references to Nicholas Flamel, who gained posthumous reputation as an alchemist, and also to his wife Perenelle. This marks one of the very rare occasions in the whole heptalogy of the Harry Potter series when historical figures become characters in the book. The decision to alter the title was clearly a marketing strategy, as the publisher believed that the term "philosopher" might not be familiar to the young American reader ${ }^{16}$ and moreover might be off-putting for the parent-buyer as this term indicates a certain degree of seriousness, which

\footnotetext{
14 Both are types of fish.

15 Britannica: philosopher's stone. [n.d.]. In Encyclopcedia Britannica online [online:] www.britannica.com/EBchecked/topic/456733/philosophers-stone - 6.06.2018.

16 Radosh, D. [1999, September 20]. Why American Kids Don't Consider Harry Potter an Insufferable Prig, The New Yorker, pp. 54, 56, [online:] www.newyo-
} 
might not be desirable in books for children and young readers. The term "sorcerer" in the title is also a reinforcement of the fact that the book is mostly focused on magic and possibly might be more appealing to the potential buyer. The 2001 film adaptation of the book was also released in the United States under Harry Potter and the Sorcerer's Stone, but the website Pottermore, which was developed and released by J. K. Rowling in 2012, refers to the book only by its British title. ${ }^{17} \mathrm{I}$ also found that a collection of stories by Roald Dahl was published in Britain under the title The Great Automatic Grammatizator, which was changed in the United States to The Umbrella Man and Other Stories. As well, Aldous Huxley's short story collection Little Mexican was published in America as Young Archimedes. The title of Philip Pullman's novel Northern Lights was changed by American editors into The Golden Compass and the film adaptation of the book was released under the American title in all markets. Editors at Dial Books for Young Readers changed the title of Dyan Sheldon's The Garden (published by Hutchinson in 1993), as the cover work by Gary Blythe (used in both versions) showed what is in America "a backyard", and The Backyard was seen as too mundane so they finally settled on Under the Moon (published in 1993) [Whitehead 1996].

\section{Influence of the publisher and changes by the author}

There are other changes often triggered by the publishers that transform the texts even further. This was almost the case with Garry Kilworth's The Electric Kid, mentioned above. Whitehead [1997] writes about concerns of one editor and how they influenced the changes to the text of June Oldham's Foundling, made by the author herself:

One of editor Melanie Kroupa's main concerns about Oldham's text was the "slow moving" opening section. "I worry that we'll lose young readers before they've really given the book a chance," she wrote to Oldham. While questioning the assumption that "we must have them zapped in the first halfpage," Oldham recast the four opening chapters, quickening the pace and plunging the reader immediately into the action. The speeded-up tempo of the

rker.com/books/why_american_kids_dont_consider_harry_potter_an_insufferable_prig - 11.04.2008.

17 Rowling "Pottermore", [n.d.], [online:] https://www.pottermore.com/ writing-by-jk-rowling/the-philosophers-stone - 6.06.2018. 
opening resonates throughout the novel, and Oldham feels that in many ways Found is a different book from Foundling, with more pace and less poetry [Whitehead 1997: n.p.].

The American editor of the Harry Potter series convinced J. K. Rowling that such words as "jumper" for a pullover sweater should be changed, because "jumper" in American English is used to denote a "pinafore", which is a type of dress and thus might be misleading to American readers. ${ }^{18}$ As the publisher of Scholastic, Arthur Levine claimed in an interview for The New Yorker:

I wasn't trying to, quote, 'Americanize' them [...]. What I was trying to do is translate, which I think is different. I wanted to make sure that an American child reading the books would have the same literary experience that a British kid would have. A kid should be confused or challenged when the author wants the kid to be confused or challenged and not because of a difference of language [Radosh 1999: n.p.]

The idea of this "American translation" has been widely criticized by the series' readers, as well as J. K. Rowling herself [Nel 2003]. There are many changes that actually fail to give an American reader "the same literary experience that a British kid would have". It might be argued that additional explanations or even explanations outside the text, perhaps as footnotes, a preface, or a postscript (as for instance in the Polish translation of the books) would have been in many cases a better choice, as it would also be a chance for readers to broaden their knowledge. Although the American version is not free from mistakes, inconsistencies, and changes that are difficult to justify, the Scholastic editors also eliminated some errors from the original text, and several of these corrections have made their way back into the later Bloomsbury editions (see below).

There are also cases when authors edit their own work for the American market. C. S. Lewis in The Chronicles of Narnia, (published by Harper Collins in the USA) changed the text, e.g. "Maugrim" to "Fenris Ulf", and the subsequent "Peter Wolf's-bane" to "Peter Fenris-bane" [Duriez 201: 190]. After the initial release of the books on the American market the order of books was altered from the original publication sequence to chronological [Ford 2005: xiii-xxiv].

18 Woods, A. [2000]. Success Stuns Harry Potter Author, [online:] http://www. cesnur.org/recens/potter_030.htm - 30.01.2009. 


\section{Didactizing and "toning down"}

There are also additions and changes in some books that seem to be meant to tone down or even, in a way, censor some passages, making them more "appropriate" for young readers. There are many examples of such changes in the Harry Potter series. Some changes are designed to change the behavior or utterances of teachers portrayed in the book. At the end of Harry Potter and the Chamber of Secrets, the second book in the series, a much-hated celebrity-Professor admits that most of his achievements are actually frauds as he took credit for what other witches and wizards had done. He defends himself by saying:

No one wants to read about some ugly old Armenian warlock, even if he did save a village from werewolves. He'd look dreadful on the front cover. No dress sense at all. And the witch who banished the Bandon Banshee had a hare lip. I mean, come on... ${ }^{19}$

In the American version "hare lip" is changed into "hairy chin". ${ }^{20} \mathrm{Cleft}$ lip, a "common congenital deformity in which the central to medial lip fails to fuse properly", ${ }^{21}$ was in the past usually called a "hare lip", although now the term is generally considered to be offensive. ${ }^{22}$ It is not certain why this alteration was made by the American editors. One reason might be the fact that a cleft lip could have been considered too drastic for young readers, teacher speaking disdainfully of this condition might be considered very offensive. Another might be the term itself, as it is considered offensive. In the same book, the Head of Harry's House, Professor McGonagall, can be seen shaking her fist in a student's direction during an extremely fierce sporting event. ${ }^{23}$ In the American version "fist"

19 J. K. Rowling (1998), Harry Potter and the Chamber of Secrets. London, Bloomsbury. 220.

20 J. K. Rowling (1999), Harry Potter and the Chamber of Secrets. New York, Scholastic Press. 197.

21 Britannica: cleft lip. [n.d.]. In Encyclopcedia Britannica online, [online:] www. britannica.com/EBchecked/topic/255229/cleft-lip - 6.06.2018.

22 Merriam-Webster: harelip. [n.d.]. In Merriam-Webster online, [online:] http:// www.merriam-webster.com/dictionary/harelip - 6.06.2018.

23 J. K. Rowling (1999), Harry Potter and the Prisoner of Azkaban. London, Bloomsbury. 228; J. K. Rowling (1999), Harry Potter and the Prisoner of Azkaban. New York, Scholastic Press. 229. 
is changed into "finger". ${ }^{24}$ It can be argued that a teacher shaking a fist at a student might be considered close to a physical offense or threat, while shaking a finger can be just perceived as a form of displaying disapproval.

Other changes seem to aim at making the protagonists better role models for the young audience or at making their actions less violent. In the British edition of Harry Potter and the Chamber of Secrets, Harry and his best friend Ron steal Ron's parents' car and do so without much consideration of how their parents would return home without the car. In the American version, Harry raises some objections and only after Ron states that his parents can travel back by means of magic do they take the car. ${ }^{25}$ At the end of this book Ron's broken wand is stolen from him by one of the teachers, who by accident wipes out his own memory. In the British version of the book, Ron seems unperturbed by his teacher's predicament and can even be seen grinning, ${ }^{26}$ but in the American version he is "still looking puzzled". ${ }^{27}$ In chapter two of Harry Potter and the Prisoner of Azkaban, as the main protagonist reminiscences about past visits of his hated aunt, we read: "[o]n her last visit [...] Harry had accidentally trodden on the paw of her favourite dog". ${ }^{28}$ The "paw" is changed into "tail" 29 and the reason for this change might have been again to tone it down, as stepping on a dog's tail might be considered less drastic than stepping on its paw. However, the dog in question is a small bulldog that could fit under an $\operatorname{arm}^{30}$ and most such bulldogs have naturally short tails that are not cut or docked, making it quite unlikely that anyone could tread on it.

24 J. K. Rowling (1999), Harry Potter and the Prisoner of Azkaban. New York, Scholastic Press. 311.

25 J. K. Rowling (1999), Harry Potter and the Chamber of Secrets. New York, Scholastic Press. 69.

26 J. K. Rowling (1998), Harry Potter and the Chamber of Secrets. London, Bloomsbury. 238.

27 J. K. Rowling (1999), Harry Potter and the Chamber of Secrets. New York, Scholastic Press. 324.

28 J. K. Rowling (1999), Harry Potter and the Prisoner of Azkaban. London, Bloomsbury. 19.

29 J. K. Rowling (1999), Harry Potter and the Prisoner of Azkaban. New York, Scholastic Press. 19.

30 J. K. Rowling (1999), Harry Potter and the Prisoner of Azkaban. London, Bloomsbury. 22; J. K. Rowling (1999), Harry Potter and the Prisoner of Azkaban. New York, Scholastic Press. 22. 


\section{Correcting the author}

The adaptation of the Harry Potter series to the American market was a massive undertaking. For one example I have counted, just in the first three books in the series, the addition of approximately 600 Oxford commas, the most abundant of the changes. The editors of the adaptation (they have never been named and the Scholastic editions lack any information that the books had been altered in any way for the American market) corrected some mistakes made by J. K. Rowling. As mentioned above, correcting literary work is, to say the least, a controversial issue, although it is also worth mentioning that after the publication in the USA the later editions of the book in Britain contain some corrections of the mistakes in spelling, errors in chronology, wrong choice of words, and the impossible movement of chess pieces on a chessboard, among others. One such example can be found at the end of book two when the word "ancestor" 11 is used instead of "descendant". ${ }^{32}$ Another occurs at the culmination of the first book, when the three protagonists are playing on a giant chessboard and they have to replace three chess pieces with themselves. In the first British edition of the book Ron instructs his friends: "well, Harry, you take the place of that bishop, and Hermione, you go next to him instead of that castle [...] I'm going to be a knight". ${ }^{33}$ However, in chess the rook is next to the knight, not the bishop. By "next to him" Ron might have meant "on the same side of the queen" but this would have been a strange choice of words. In the American version this is changed to: "well, Harry, you take the place of that bishop, and Hermione, you go there instead of that castle [...] I'm going to be a knight". ${ }^{34}$ At the end of the same game of chess Ron decides to sacrifice himself to win the game, and he says: "You've got to make some sacrifices! I take one step forward and she'll take me - that leaves you free to checkmate the king, Harry!". ${ }^{35}$

31 J. K. Rowling (1998), Harry Potter and the Chamber of Secrets. London, Bloomsbury. 245.

32 J. K. Rowling (1999), Harry Potter and the Chamber of Secrets. New York, Scholastic Press. 333.

33 J. K. Rowling (1997), Harry Potter and the Philosopher's Stone. London, Bloomsbury Publishing. 303.

34 J. K. Rowling (1998). Harry Potter and the Sorcerer's Stone. New York, Scholastic Press. 282.

35 J. K. Rowling (1997), Harry Potter and the Philosopher's Stone. London, Bloomsbury Publishing. 304. 
It is impossible for the knight in chess to move only one step forward as it moves two spaces and one space to the side, thus in the American edition and later British editions Ron says: "I make my move and she'll take me - that leaves you free to checkmate the king, Harry!". ${ }^{36}$

The same book introduces one of the older students in the school, Marcus Flint. He is described as "a sixth-year". ${ }^{37}$ As the highest year in Hogwart's is the seventh year, Flint should have graduated in Harry's second year, but he is still the captain of his House Quidditch team in Harry's third year in Harry Potter and the Prisoner of Azkaban. To avoid a continuity error in Harry Potter and the Sorcerer's Stone "a sixth-year" is changed to "a fifth-year" 38 in the American version and later British versions. Later when J. K. Rowling was asked to explain this she stated on her website "Either I made a mistake or he failed his exams and repeated a year. I think I prefer Marcus making the mistake". ${ }^{39}$ The series' fans still call such consistency errors "Flints". ${ }^{40}$

Harry Potter and the Prisoner of Azkaban features time travel, and in the book one scene is described twice, once in the original timeline and once again when two of the protagonists, Harry and Hermione, watch the from a different time perspective. In both versions the scene is described in this way: "Lupin, Pettigrew, and Ron clambered upward(s) without any sound of savaging branches (...) Black saw Snape up through the hole, then stood back for Harry and Hermione to pass". ${ }^{41}$ When the scene is seen by Harry and Hermione, who have travelled back in time, this order is changed in the British version: "[t]hey saw Lupin, Ron and Pettigrew clambering awkwardly out of the hole in the roots. Then came Hermi-

36 J. K. Rowling (1998). Harry Potter and the Sorcerer's Stone. New York, Scholastic Press. 283.

37 J. K. Rowling (1997), Harry Potter and the Philosopher's Stone. London, Bloomsbury Publishing. 201.

38 J. K. Rowling (1998). Harry Potter and the Sorcerer's Stone. New York, Scholastic Press. 185.

39 J. K. Rowling, [n.d.] FAQ: Why did Marcus Flint do an extra year at Hogwarts?, [online:] www.jkrowling.com/textonly/en/faq_view.cfm?id=16 - 2.02.2009.

40 Harry Potter wiki: Marcus Flint. [n.d.]. In Harry Potter wiki, [online:] http:// harrypotter.wikia.com/wiki/Marcus_Flint - 2.02.2009.

41 J. K. Rowling (1997), Harry Potter and the Philosopher's Stone. London, Bloomsbury Publishing. 278; J. K. Rowling (1999), Harry Potter and the Prisoner of Azkaban. New York, Scholastic Press. 380. 
one ... then the unconscious Snape, drifting weirdly upwards. Next came Harry and Black". ${ }^{42}$ The American version corrects this to: "[t]hey saw Lupin, Pettigrew, and Ron clambering awkwardly out of the hole in the roots ... followed by the unconscious Snape, drifting weirdly upward. Next came Harry, Hermione, and Black".

\section{Changes outside the text}

Not only is the text of the books altered but also, as illustrations and cover work are often very important in books targeted at a young readership, the Americanized adaptations of British books often feature changes in the artwork. However, the reasoning behind them and the end effect are sometimes doubtful, and in some cases the artwork triggers changes, as shown by the example of Dyan Sheldon's The Garden, published as Under the Moon (see above). The left-hand traffic system is one reason to make changes. The images on covers are altered so that the vehicles that in the original drive on the left now drive on the right. What is more, some British artists of covers and illustrations, anticipating the book being sold in right-handed traffic countries, place the steering wheel in the center, e.g. Judy Hindley's The Big Red Bus (published by Collins in Britain in 1985 and Candlewick in the USA in 1995), illustrated by William Benedict, which has the same cover art for both versions, with the steering wheel firmly in the center [Whitehead 1996].

\section{Changes in literature and films for adult viewers}

It is true that books marketed for children or young readers are usually subject to modifications when they are released on the other side of the ocean. Books for adult readers sometimes meet this fate as well. An interesting example of this is the rewriting of Bridget Jones's Diary by Helen Fielding for the US market. The American editors did not stop only at altering spelling and punctuation, they also altered cultural references in this very British book. "Bruce Forsyth" changes into "Bob Hope"; "It is too Brian Rix..." becomes "It is too French farce..."; and "Shakira Caine look-alike" is transformed into "Faye Dunaway look-alike", among others [c.f. Seppälä 2008].

42 J. K. Rowling (1997), Harry Potter and the Philosopher's Stone. London, Bloomsbury Publishing. 289. 
It is also worth mentioning that there are literary works intended for the adult reader which have their titles altered for the American market. I found Agatha Christie's books to be a good example, as many of them had their titles changed by the publishers, e.g. After the Funeral became Funerals are Fatal, and Death in the Clouds was published in the United States under Death in the Air. Dumb Witness, Five Little Pigs, Hickory Dickory Dock, The Hollow, and Lord Edgeware Dies were changed into Poirot Loses a Client, Murder in Retrospect, Hickory Dickory Death, Murder After Hours, and Thirteen at Dinner respectively. One of her most famous detective stories featuring Hercule Poirot, Murder on the Orient Express was published in America under the title Murder in the Calais Coach to avoid confusion with the 1932 Graham Greene novel Stamboul Train, which had been published in the United States as Orient Express [Wagstaff and Poole 2004]. The film adaptations of the book have the British title. And Then There Were None was originally published in Britain under Ten Little Niggers, a reference to a song that serves as a plot point. The American title was taken from the American version of this song, although the title Ten Little Indians was also used in some American editions. Joseph Conrad's The Nigger of the 'Narcissus': A Tale of the Sea was first published in the United States as The Children of the Sea: A Tale of the Forecastle, which was forced by the editor, who claimed that no one would buy a book with "nigger" in its title, not because it was offensive but because a book about a black man would not sell [Orr 2009]. The Golden Fleece by Robert Graves was changed in America into Hercules, My Shipmate.

Interestingly, not only books are altered when released to the American market, as there are cases of changes in films and television series. One such film adaptation for the American market is the widely discussed redubbing of the first twenty minutes of the film Trainspotting (1996). The beginning of the film includes passages in Edinburgh vernacular, which the motion picture's distributor feared would be incomprehensible for American viewers. Other films that were re-dubbed or partially dubbed for the American market include My Left Foot (1989), In the Name of the Father (1993), and Mad Max (1979), where the original's Australian English was re-dubbed by an American cast. ${ }^{43}$

43 The independent: "Trainspotting" made easy - for Americans. [1996], [online:] www.independent.co.uk/news/uk/home-news/trainspotting-made-easy--for- 


\section{American texts changed for British audiences}

The vastness of the American market and the prospect of publishing their work there seems to be one the reason why British authors and editors agree to some changes. However, there are also American books that enter the British market with their texts altered and this seems to be a growing trend, although also not a new one. Scott Fitzgerald's The Great Gatsby had several changes when it was published by Penguin Books in Britain. They included spelling (e.g. "savors" into "savours"), punctuation (e.g. "went toward the little office mingling immediately" into "went toward the little office, mingling immediately") different lexical items (e.g. "the ninth machine-gun battalion" into "the Twenty-eighth Infantry", "I said" into "I began", "Biloxi, Mississippi" into "Biloxi, Tennessee") and also omissions and additions [Paatero 2002]. Whitehead [1997] gives an example from Rosemary Wells's Shy Charles (published by Dial Books in the US in 1988 and by Puffin Books in the UK in 1992), where at the end of the story, the protagonist buries his face in his mother's coat to escape praise: "And everyone shouted, / 'Thank you, Charles'/ But Charles said.../ Zero". The last part changes in Britain into "Charles said. / Not a word".

\section{Conclusions}

Many British literary works are altered when entering the American market and the number of American books that undergo changes before being marketed in the United Kingdom is smaller, but it should not be neglected. The works that are most frequently altered are books targeted at young readers. The usual justification for alterations is that unknown items might be discouraging for intended readers and potential buyers of books and this could cause the sales to plummet, as competition on the American book market is undoubtedly fierce. This explanation is in many cases unconvincing. Moreover, in many cases, a change of one word can alter titles of works, even whole texts. I believe it may be argued that in today's world, where access to information is quick and easy, such heavy modifications are not necessary as they deprive the reader of an opportunity to acquire new knowledge of the world and learn about different varieties of English. It is also worth mentioning that there are individuals

americans-1349197.html-10.06.2018. 
whose mother tongue is not English and who still enjoy reading English books and watching English language films without that many problems, depending of course on their language proficiency, so it can be argued that even though some changes might benefit young readers (e.g. reinforcing correct spelling or usage of punctuation), alterations that interfere with the text more are not necessary for the reader to have an enjoyable reading experience.

\section{REFERENCES}

Briggs, J. (1989), "Reading Children's Books", Essays in Criticism, 39(1), pp. 1-17, https://doi.org/10.1093/eic/XXXIX.1.1.

Chaudhuri, S. (August 9, 2000), "Harry Potter and the Transfiguration of Language", The New Straits Times.

Crystal, D. (1997), English as a Global Language, Cambridge University Press, Cambridge.

David, E., Simons, G., Fennig, C. (2019), Ethnologue: Languages of the World. Twenty-second Edition, SIL International, Dallas.

Duriez, C. (2013), The A-Z of C. S. Lewis: An Encyclopaedia of his Life, Thought, and Writings, Lion Books, Oxford.

Ford, P. (2005), Companion to Narnia: A Complete Guide to the Magical World of C.S. Lewis's The Chronicles of Narnia, Harper, San Francisco.

Fowler, H., Burchfield, R. (1996), The New Fowler's Modern English Usage, $3^{\text {rd }}$ Edition, Clarendon Press, Oxford.

Hejwowski, K. (2004), Translation: A Cognitive-communicative Approach, Wydawnictwo Wszechnicy Mazurskiej, Olecko.

Hoad, T. F. (1986), The Concise Oxford Dictionary of English Etymology, Oxford/Clarendon Press, Oxford.

Jakobson, R. (1987), Language in Literature, The Belknap of Harvard University Press, Cambridge, Mass.

Janicki, K. (1977), Elements of British and American English, Państwowe Wydawnictwo Naukowe, Warszawa.

Klingberg, G. (1986), Children's Fiction in the Hands of the Translator, CWK Gleerup, Lund.

Klingberg, G. (2008), Facets of Children's Literature Research: Collected and Revised Writings, Svenska barnboksinstitutet, Stockholm.

Krapp, G. P. (1925), The English Language in America, The Century Co, New York. 
Lovinger, P. W. (2000), The Penguin Dictionary of American English Usage and Style: A Readable Reference Book, Illuminating Thousands of Traps that Snare Writers and Speakers, Penguin Reference, New York.

Marckwardt, A. H., Dillard, J. L. (1980), American English, $2^{\text {nd }}$ Edition, Oxford University Press, New York.

Britannica: cleft lip. [n.d.], in: Encyclopcedia Britannica online, [online:] www. britannica.com/EBchecked/topic/255229/cleft-lip - 6.06.2018.

Britannica: philosopher's stone. [n.d.], in: Encyclopcedia Britannica online, [online:] www.britannica.com/EBchecked/topic/456733/ philosophers-stone - 6.06.2018.

Harry Potter wiki: Marcus Flint. [n.d.], in: Harry Potter wiki, [online:] http://harrypotter.wikia.com/wiki/Marcus_Flint-2.02.2009.

Marckwardt, A. H., Quirk, R. (1964), A Common Language: British and American English; Conversations between Albert H. Marckwardt [and] Randolph Quirk, Printed by Cox and Wyman, London.

Mencken, H. L. (1919), The American Language: An Inquiry into the Development of English in the United States, A.A. Knopf, New York.

Merriam-Webster: harelip. [n.d.], in: Merriam-Webster online, [online:] http:// www.merriam-webster.com/dictionary/harelip - 6.06.2018.

Miller, J. S. (2000), Something Completely Different British Television and American Culture, University of Minnesota Press, Minneapolis.

Nel, P. (2003). You Say “Jelly” I say “Jell-O”? Harry Potter and the Transfiguration of Language, in: L. A. Whited (ed.), Ivory Tower and Harry Potter, University of Missouri Press, Columbia, Missouri, pp. 261-284.

Orr, L., Billy, T. (1999), A Joseph Conrad Companion, Greenwood Press, Westport, Connecticut.

Paatero, N. (2002), Differences between British and American English in Two Versions of F. Scott Fitzgerald's "The Great Gatsby", [online:] https:// www15.uta.fi/FAST/US1/LP/np-great.html - 30.01.2018

Peters, P. (2004), The Cambridge Guide to English Usage, Cambridge University Press, Cambridge, https://doi.org/10.1017/CBO9780511487040.

Radosh, D. (1999, September 20), "Why American Kids don’t Consider Harry Potter an Insufferable Prig", The New Yorker: 54, 56, [online:] www.newyorker.com/books/why_american_kids_dont_consider_harry_potter_an_insufferable_prig - 11.04.2008.

Rowling, J. K. (1998), Harry Potter and the Chamber of Secrets, Bloomsbury Publishing, London. 
Rowling, J. K. (1998), Harry Potter and the Sorcerer's Stone, Scholastic Press, New York.

Rowling, J. K. (1999), Harry Potter and the Chamber of Secrets, Scholastic Press, New York.

Rowling, J. K. (1999), Harry Potter and the Prisoner of Azkaban, Bloomsbury Publishing, London.

Rowling, J. K. (1999), Harry Potter and the Prisoner of Azkaban, Scholastic Press, New York.

Rowling, J. K. (n.d.), "Pottermore", [online:] https://www.pottermore.com/ writing-by-jk-rowling/the-philosophers-stone - 6.06.2018.

Rowling, J. K. (1997), Harry Potter and the Philosopher's Stone, Bloomsbury Publishing, London.

Seppälä, J. (2008), Differences in the British and American Versions of "Bridget Jones's Diary", by Helen Fielding, [online:] https://www15.uta.fi/FAST/ US1/P1/js-jones.html - 30.01.2018.

Shavit, Z. (1986), Poetics of Children's Literature, University of Georgia Press, Athens, Georgia.

Shell, M. (2002), American Babel: Literatures of the United States from Abnaki to Zuni, Harvard University Press, Cambridge, Mass.

Trask, R. L. (1997), The Penguin Guide to Punctuation, Penguin Books, London.

Wagstaff, V., Poole, S. (2004), Agatha Christie. A Reader's Companion, Aurum Press, London.

Whitehead, J. (November/December 1996), “"This is Not What I Wrote!': The Americanization of British Children's Books - part 1", Horn Book Magazine, 6(72), pp. 687-693.

Whitehead, J. (January/February 1997), “'This is Not What I Wrote!': The Americanization of British Children's Books - part 2", Horn Book Magazine, 1(73), pp. 27-34.

Woods, A. (2000), Success Stuns Harry Potter Author, [online:] http://www. cesnur.org/recens/potter_030.htm - 30.01.2018.

\section{Abstract}

The paper reviews instances of intralingual translation between British and American English. Its main focus is the translation of literary texts aimed and children and young readers which were written in Britain and then altered before being released on the American market. Examples of cases where originally American texts were altered for British readers, 
a less common trend, are also provided. The text explores typical differences between British and American English, the position of children's literature and the motivations behind the changes, examples of alteration to titles of books, changes that trigger changes of larger portions of texts, alterations to the style of the books, and areas where the authors of the translations corrected authors' mistakes. Most of the examples are based on previously published works which analyzed intralingual translation between British and American English in children's literature, with some taken from unpublished research by the author. The paper was written with the hope that it will help create more awareness of the existence of such translations, especially since in most cases no information that such changes were made is provided within or outside the literary texts discussed in this paper.

Keywords: translation, rewording, British, American, intralingual translation 